
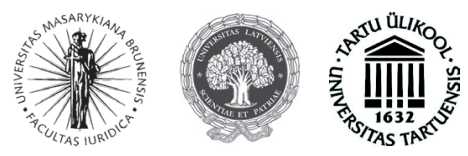

ISSN 1392-6195 (print) ISSN 2029-2058 (online) JURISPRUDENCIJA JURISPRUDENCE 2013, 20(3), p. 1231-1248.

\title{
NATIONAL REGULATORY AUTHORITIES IN THE ENERGY SECTOR OF UKRAINE: PROBLEMS OF THE LEGAL STATUS IN THE CONTEXT OF THE EUROPEAN INTEGRATION AND THE ADMINISTRATIVE REFORM
}

\author{
Yuliya Vashchenko \\ Taras Shevchenko National University of Kyiv, Faculty of Law, \\ Department of Administrative Law \\ Volodymyrska street, 64/13, 01601, Kiev, Ukraine \\ Telephone (+380) 672892649 \\ E-mail: y_vashchenko@univ.kiev.ua \\ Received on 15 August, 2013; accepted on 20 September 2013 \\ doi:10.13165/JUR-13-20-3-19
}

\begin{abstract}
Annotation. The article explores the problems of the legal status of the regulatory authorities in the energy sector of Ukraine in the context of the administrative reform currently taking place in the Ukraine and the fulfillment of the EU requirements in this sphere. Based on the analysis of the EU legislation, in particular Directive 2009/72/EC of the European Parliament and the Council of 13 July 2009 concerning common rules for the internal market in electricity and repealing Directive 2003/54/EC and Directive 2009/73/EC of the European Parliament and the Council of 13 July 2009 concerning common rules for the internal market in natural gas and repealing Directive 2003/55/EC, and the experience of Ukraine in the field of energy regulation, the author of this article supports granting the special legal status to the national regulatory authorities in the energy sector of Ukraine and their separation from the system of state executive bodies, however, recommends to stipulate in the Constitution of Ukraine the provisions, regarding the organizational legal form and
\end{abstract}


the establishment procedure of such bodies, the appointment and dismissal procedure for their management and members, the peculiarities of the relations of these bodies with the President of Ukraine, the Parliament of Ukraine and the Government of Ukraine.

Keywords: energy regulation, energy regulator, energy policy, national regulatory authorities, administrative reform.

\section{Introduction}

Administrative reform is currently taking place in the Ukraine. Therefore, researchers, primarily, the representatives of Administrative Law science, shall provide the efficient solutions for the relevant tasks connected with the optimization of the public authorities system. The legal status of the regulatory authorities in general and the national regulatory authorities in the energy sector of Ukraine (National Energy Regulatory Commission and National Communal Services Regulatory Commission (in part of the district heating supply)) in particular are examples of such important tasks. Some time ago, the organizational legal form and the place of these bodies in the public authorities system of Ukraine were strictly defined by the legislation of Ukraine. These authorities were part of the system of bodies of executive power and had a status of central state executive bodies. However, significant changes have been made as a result of the reforms in the system of state executive bodies that have taken place in the recent years. The start of such reforms was made by Presidential Decree "On Optimization of the System of State Executive Bodies” of 09.12.2010 №1085/20101 and continued by Law of Ukraine "On Central State Executive Bodies" №3166-VI of 17.03.20112 and Law of Ukraine "On Changes to Some Legal Acts of Ukraine regarding National Commissions Conduct State Regulation of Natural Monopolies, in the Sphere of Communication and Informatization, Bond and Financial Markets” №3610-VI of 07.07.20113. National commissions were separated from the system of state executive bodies and granted the status of state collegial bodies. In accordance with the new legislation, these bodies were created by the President of Ukraine. Today, they are responsible to the President of Ukraine and are accountable to the Verkhovna Rada of Ukraine. As to the regulator in the energy sector, such changes aimed, in particular, at the fulfillment of the requirements of the EU legislation, regarding the independence of the energy regulatory authority, primarily, Directive 2009/72/EC of the European Parliament and the Council of 13 July 2009 concerning common rules for the internal market in electricity and repealing

1 Ukaz Prezydenta Ukrainy "Pro optymizaciju centralnyh organiv vykonavchoi vlady". Urjadovyj kurjer, 2010, №234.

2 Zakon Ukrainy "Pro centralni organy vykonavchoi vlady". Golos Ukrainy, 2011, №65.

3 Zakon Ukrainy "Pro vnesennja zmin do dejakyh zakonodavchyh aktiv Ukrainy shhodo nacionalnyh komisij, shho zdijsnjujut derzhavne reguljuvannja pryrodnyh monopolij, u sferi zvjazku ta informatyzacii, rynkiv cinnyh paperiv i finansovyh rynkiv". Golos Ukrainy, 2011, №145. 
Directive 2003/54/EC4 and Directive 2009/73/EC of the European Parliament and the Council of 13 July 2009 concerning common rules for the internal market in natural gas and repealing Directive 2003/55/EC5. However, the legal status of state collegial bodies in general and the legal status of energy regulators in particular are still under discussion, considering the provisions of the Constitution of Ukraine. The Constitution of Ukraine does not define such types of state bodies as state collegial bodies or national regulatory commissions. The issues refer to the legal status of national regulatory authorities in the conditions of the administrative reform in the Ukraine, partially explored in the papers of Ukrainian researchers6. However, the problems of the legal status of national regulatory authorities in the energy sector of Ukraine, in particular, in the context of the fulfillment of the EU requirements, have not been a subject of complex research yet. Therefore, this article aims to analyse the problems of the legal status of national regulatory authorities in the energy sector of Ukraine in the light of the administrative reform and the fulfillment of the EU requirements, as well as the development of the recommendations of the enhancement of the legislation of Ukraine in this sphere.

\section{Legal Framework of Regulatory Authorities in the Energy Sector of Ukraine and the EU Requirements}

Energy sector is one of the most important spheres of cooperation between the EU and the Ukraine.

On 1 February, 2011, Ukraine became a full-fledged member of the Energy Community. The Protocol Concerning the Accession of Ukraine to the Treaty Establishing the Energy Community was signed on 24 September, 2010 and ratified by Law of Ukraine №2787-VI of 15 December $2010^{7}$.

Pursuant to the Decision of the Ministerial Council of the Energy Community D/2011/02/MC-EnC of 6 October $2011^{8}$, Ukraine shall bring into force laws, regulations

4 Directive 2009/72/EC of the European Parliament and the Council of 13 July 2009 concerning common rules for the internal market in electricity and repealing Directive 2003/54/EC [2009] OJ, L211/55.

5 Directive 2009/73/EC of the European Parliament and the Council of 13 July 2009 concerning common rules for the internal market in natural gas and repealing Directive 2003/55/EC [2009] OJ, L211/94.

6 Vashhenko, Ju. Problemy pravovogo statusu Nacionalnoi komisii reguljuvannja rynku komunalnyh poslug Ukrainy. Visnyk Kyivskogo nacionalnogo universytetu imeni Tarasa Shevchenka: jurydychni nauky. 2010, 85: 22-26; Vashhenko, Ju. Nacionalni komisii reguljuvannja pryrodnyh monopolij v systemi organiv derzhavnoi vlady v Ukraini Pivdennoukrainskyj pravnychyj chasopys, 2012, №3 S.137-139; Melnyk, R.; Petrov, Je. Fantom u systemi organiv derzhavnoi vlady abo do pytannja pro pravovyj status nacionalnyh komisij reguljuvannja pryrodnyh monopolij. Visnyk Zaporizkogo nacionalnogo universytetu. 2012, 1(1): 214-219.

7 Zakon Ukrainy "Pro ratyfikaciju Protokolu pro pryjednannja Ukrainy do Dogovoru pro zasnuvannja Energetychnogo Spivtovarystva”. Oficijnyj Visnyk Ukrainy. 2011, №1.

8 Decision of the Ministerial Council of the Energy Community D/2011/02/MC-EnC: Decision of the implementation of Directive 2009/72/EC, Directive 2009/73/EC, Regulation (EC) №714/2009 and Regulation (EC) №715/2009 and amending Articles 11 and 59 of the Energy Community Treaty. [interactive]. [accessed on 14-08-2013]. <http://www.energy-community.org/pls/portal/docs/1146182.PDF>. 
and administrative provisions necessary to comply with Directive 2009/72/EC and Directive 2009/73/EC.

According to the Directives mentioned above, the Member States shall designate a single national regulatory authority at a national level. Concerning this requirement, the European Commission explained that it is no longer possible for a Member State to designate at the national level one regulatory authority to deal with one of the regulatory duties listed in the Electricity and Gas Directives (or Regulations), such as network tariffs, and a different (regulatory or other) authority to deal with another duty of the regulatory authority. It means that a single national regulatory authority at the national level must be entrusted with all regulatory duties provided in the Electricity and Gas Directives. It is important to notice that the core duties of the national regulator can no longer be split between the regulator and the Industrial Ministry ${ }^{9}$.

Pursuant to Article 35 of Directive 2009/72/EC and Article 39 of Directive 2009/73/ $\mathrm{EC}$, the Member States shall guarantee the independence of the regulatory authority and shall ensure that it exercises its powers impartially and transparently.

There are two key elements of the regulator's independence upon these Directives:

- the independence within the system of state bodies;

- the independence from the regulated industry.

As to the independence within the system of state bodies, the Member States shall ensure, in particular, that the regulator is legally distinct and functionally independent from any other public entity; its staff and the persons responsible for its management do not seek or take direct instructions from any government or other public entity when carrying out the regulatory tasks. However, the regulatory authority can cooperate, as appropriate, with other national state bodies, but not concerning the issues connected with its regulatory tasks defined by the Directives. As to the cooperation of the regulatory authority with other state bodies, in particular with the Government, competition authorities and regional regulators, the explanations of the European Commission shall be taken into consideration, e.g., the European Commission explains that, depending on the national constitution, it could be in the government's competency to determine the policy framework, within which the regulator must operate. However, general energy policy guidelines issued by the government must not encroach on the regulator's independence and autonomy ${ }^{10}$.

9 Commission Staff Working Paper. Interpretative Note on Directive 2009/72/EC Concerning Common Rules for the Internal Market in Electricity and Directive 2009/73/EC Concerning Common Rules for the Internal Market in Natural Gas. Brussels, 22 January, 2010 [interactive]. [accessed on 14-08-2013]. $<$ http://ec.europa.eu/energy/gas_electricity/interpretative_notes/doc/implementation_notes/2010_01_21_ the_regulatory_authorities.pdf $>$.

10 Commission Staff Working Paper. Interpretative Note on Directive 2009/72/EC Concerning Common Rules for the Internal Market in Electricity and Directive 2009/73/EC Concerning Common Rules for the Internal Market in Natural Gas. Brussels, 22 January, 2010 [interactive]. [accessed on 14-08-2013]. $<\mathrm{http} / /$ ec.europa.eu/energy/gas_electricity/interpretative_notes/doc/implementation_notes/2010_01_21_ the_regulatory_authorities.pdf $>$. 
Pursuant to the Directives mentioned above, the Member States shall ensure that the regulatory authority can take autonomous decisions, independently from any political body, and has separate annual budget allocations, with autonomy in the implementation of the allocated budget, and adequate human and financial resources to carry out its duties; and the members of the board of the regulatory authority or, in the absence of a board, the regulatory authority's top management are appointed for a fixed term of five up to seven years, renewable once. The Member States shall also ensure an appropriate rotation scheme for the board or the top management. The members of the board (top management) may be relieved from office during their term only if they no longer fulfill the conditions set out in the Directives or have been guilty of misconduct under national law.

It should be mentioned that the issues regarding the legal status of the regulatory authority in general and the independence of energy regulators in particular are a subject of the researches of scientists from different countries ${ }^{11}$, e.g., A. Larsen, L. H. Pedersen, E. M. Sorensen and O. J. Olsen ${ }^{12}$ consider the following three dimensions of regulatory independence:

1. An arm's-length relationship with the government, which will also include features of organizational autonomy, such as earmarked funding and the exception from restrictive civil service salary rules.

2. An arm's-length relationship with the stakeholders.

3. Scope of independent decision making.

As to the regulator's independence from the Government, the authors mentioned above stress the importance of a stable source of funding, e.g. by a fee levied on the regulated industries and the authority to control appointment, allocation, promotion, dismissal and salary policies in relation to the regulatory authority's staff ${ }^{13}$.

Considering that, Ukraine as a member of the Energy Community shall guarantee the independence of its national regulatory authorities in the energy sector in accordance with the EU requirements, primarily the Electricity and Gas Directives.

11 Gilardi, F. Explaining Delegation to Independent Regulatory Agencies: The Role of Political Uncertainty. [interactive]. [accessed on 14-08-2013]. <http://onlinelibrary.wiley.com/doi/10.1002/j.1662-6370.2002. tb00336.x/pdf>; Hanretty, C. and Koop, C. De Jure and de Facto Independence of Regulatory Agencies. March, 2010 [interactive]. [accessed on 14-08-2013]. <http://chrishanretty.co.uk/blog/wp-content/ uploads/2010/03/hanretty_koop_psa2010.pdf>; Vasconcelos, J. Energy Regulation in Europe: Regulatory Policies and Politics of Regulation. European Review of Energy Markets. 2009, (3, 3) [interactive]. [accessed on 14-08-2013]. <http://www-55.mech.kuleuven.be/european-review-of-energy-market/ EREM_9-_Comment_Jorge_Vasconcelos.pdf $>$.

12 Larsen, A.; Pedersen, L.H.; Sorensen, E.M.; Olsen, O.J. Independent Regulatory Authorities in Europe. [interactive]. [accessed on 14-08-2013]. <http://sessa.eu.com/documents/wp/D73.1-Larsen.pdf>.

13 Larsen, A.; Pedersen, L.H.; Sorensen, E.M.; Olsen, O.J. Independent Regulatory Authorities in Europe. [interactive]. [accessed on 14-08-2013]. <http://sessa.eu.com/documents/wp/D73.1-Larsen.pdf >. 


\section{The Legal Status of National Regulatory Authorities in the Energy Sector of Ukraine: Background Analysis}

\subsection{National Energy Regulatory Commission of Ukraine}

In spite of the young age of Ukrainian independence and the transition period from the command administrative economy to the market economy, the energy regulation in Ukraine has its own history.

The first regulator in energy sphere was established in 1994 according to Presidential Decree №738/94 of 8 December $1994^{14}$, which was the National Electricity Regulatory Commission. The regulator was responsible for the encouragement of the development of the competition in the sphere of electricity generation, transmission and supply, licensing in these spheres and license provisions control. In addition, it was responsible for the development of price policy, electricity tariffs settlements, electricity consumers rights protection and the development and approval of rules of electricity use.

Therefore, initially, the regulator had responsibilities in the field of electricity. However, the regulated sphere gradually became wider, e.g., in accordance with Presidential Decree №1167/2000 of 30 October $2000^{15}$, the National Electricity Regulatory Commission was entrusted with the duty to regulate the activity of the subjects of natural monopolies in the fields of natural and oil gas pipeline transportation and its distribution, cross-country pipeline transportation of oil, oil products and other substances, as well as regulation of the activity of the subjects in adjacent markets in the field of natural gas transportation and natural gas storage in volumes exceed the level defined by the rules and conditions of conduct of entrepreneurial activity in natural gas storage.

It should be mentioned that in accordance with the Regulation on the National Electricity Regulatory Commission approved by Presidential Decree №213/95 of 14 March $1995^{16}$, the Commission was defined as an independent non-departmental permanent state body. It means that from the early beginning there was an understanding among the professionals that the regulator should have special legal status. This approach also remained in the Regulation on the National Electricity Regulatory Commission approved by Presidential Decree "On Issues of the National Electricity Regulatory Commission of Ukraine” №335/98 of 21 April $1998^{17}$.

14 Ukaz Prezydenta Ukrainy "Pro Nacionalnu komisiju z pytan reguljuvannja elektroenergetyky". 1994. [interactive]. [accessed 2013-08-14]. <http://zakon4.rada.gov.ua/laws/show/738/94>.

15 Ukaz Prezydenta Ukrainy "Pytannja Nacionalnoi komisii reguljuvannja elektroenergetyky Ukrainy". Oficijnyj Visnyk Ukrainy. 2000, №44.

16 Ukaz Prezydenta Ukrainy "Pro zahody shhodo zabezpechennja dijalnosti Nacionalnoi komisii z pytan reguljuvannja elektroenergetyky Ukrainy”. Urjadovyj kurjer. 1995, №43-44.

17 Ukaz Prezydenta Ukrainy "Pytannja Nacionalnoi komisii reguljuvannja elektroenergetyky Ukrainy". Oficijnyj Visnyk Ukrainy. 1998, №16. 
The Law of Ukraine "On Electricity" №575/97-BP of 16 October $1997^{18}$ defined the National Electricity Regulatory Commission as a body of state regulation of the activity in the sphere of electricity. However, there were no special provisions regarding the organizational legal form of such state body and its place in the system of state bodies of Ukraine.

The information regarding the place of the electricity regulator in the system of state bodies during the initial period can be found in the Scheme of Organization and Cooperation of Central State Executive Bodies (Appendix to Presidential Decree "On Changes in the Central Executive State Bodies Structure” №1573/99 of 15 December $\left.1999^{19}\right)$. According to this legal act, the National Electricity Regulatory Commission of Ukraine was defined as a central state executive body with a special status.

A general legal framework for the state regulation in the spheres of natural monopolies and adjacent markets was stipulated by the Law of Ukraine "On Natural Monopolies” №1682-III of 20 April 200020. In accordance with Article 5 of this Law, pipeline transportation of oil and oil products, pipeline transportation and distribution of natural and oil gas, pipeline transportation of other substances, electricity transmission and distribution and district heating supply were defined as spheres of natural monopolies. Pursuant to Article 6 of this Law, supply of pipeline transported natural gas and other substances, storage of natural gas in volumes exceed the level stipulated by rules and conditions of conduct of entrepreneurial activity in natural gas storage (license conditions), electricity generation in volumes exceed the level stipulated by rules and conditions of conduct of entrepreneurial activity in electricity generation (license conditions), electricity supply, heat generation (except the use of heat only for internal production needs) in volumes exceed the level stipulated by rules and conditions of conduct of entrepreneurial activity in heat generation (license conditions) were defined as adjacent markets.

According to Article 4 of the Law mentioned above, state regulation in the spheres of natural monopolies and in adjacent markets were conducted by national natural monopolies regulatory commissions. Pursuant to Article 11 of this Law, national natural monopolies regulatory commissions were defined as central state executive bodies with a special status. However, the changes to the Regulation on National Electricity Regulatory Commission approved by Presidential Decree "On Issues of National Electricity Regulatory Commission of Ukraine” №335/98 of 21 April 1998 were not made, but Presidential Decree №1 167/2000 of 30 October 2000 stipulated that considering the approval of Law of Ukraine "On Natural Monopolies" and in accordance with Presidential Decree of 15 December 1999 №1572 "On System of Central State Executive Bodies", the National Electricity Regulatory Commission was a central state executive body with a special status, subordinated and accountable to the President of Ukraine. The National Electricity Regulatory Commission was also referred to the

18 Zakon Ukrainy "Pro elektroenergetyku”. Oficijnyj Visnyk Ukrainy. 1997, №46.

19 Ukaz Prezydenta Ukrainy "Pro zminy u strukturi centralnyh organiv vykonavchoi vlady". Oficijnyj Visnyk Ukrainy. 1999, №50.

20 Zakon Ukrainy “Pro pryrodni monopolii’”. Vidomosti Verhovnoi Rady Ukrai’ny. 2000, №30. 
central state executive bodies with a special status by Presidential Decree №1784/2005 of 19 December 2005 "On Changes to the Scheme of Organization and Cooperation of Central State Executive Bodies"21.

Therefore, the legislation from the early beginning of the establishment of the energy regulator included different provisions regarding the organizational legal form of this authority and its place in the system of state bodies. On the one hand, the Regulations on the National Electricity Regulatory Commission of Ukraine defined the regulator as an independent non-departmental permanent state body. On the other hand, the Law of Ukraine "On Natural Monopolies" and Presidential Decree "On Changes in the Central Executive State Bodies Structure” №1573/99 of 15 December 1999 referred the regulators in the sphere of natural monopolies to the group of central state executive bodies with a special status.

Despite the existence of the basic legal regulation in the sphere of natural monopolies, there were many unsolved problems. Considering that, ineffective mechanism of state regulation of natural monopolies was defined as one of the real and potential challenges for the national security of Ukraine in Article 7 of the Law of Ukraine "On Framework of National Security of Ukraine" №964-IV of 19 June $2003^{22}$. Therefore, specialists tried to find appropriate solutions for the enhancement of the natural monopolies regulatory mechanism, based on the analysis of Ukrainian practice and the best international experience. As a result of such work, the Concept of Enhancement of Natural Monopolies State Regulation was approved by Presidential Decree №921/2007 of 27 September $2007^{23}$. This legal act includes special provisions devoted to the issues of legal status of the regulatory authorities and their role and place in the system of state bodies.

First of all, it was stipulated that the status of natural monopolies regulatory commissions as regulatory authorities in this sphere shall encourage their independence in regulatory decision making. This principle was defined as a basis for encouragement of efficient competition, transparency and nondiscrimination in the sphere of natural monopolies. Therefore, the commissions shall have the high level of independence to conduct fair, impartial, predictable and depoliticized regulation in accordance with legal norms. Considering that, it was planned to review the role and the place of natural monopolies regulatory commissions, to define the main principles of their establishment and functioning in the legislation. According to the Concept mentioned above, the legal regulation of a special status of the commissions shall be made by means of changes to the Constitution of Ukraine concerning the definition of the status and the establishment procedure and functioning of the commissions; changes to the laws regulating the relevant spheres of subjects of economic activity in the spheres of natural monopolies and adjacent markets and development and approval of the law (laws) on commissions.

21 Ukaz Prezydenta Ukrainy №1784/2005 vid 19.12.2005 "Pro vnesennja zmin do Shemy organizacii ta vzajemodii centralnyh organiv vykonavchoi vlady”. Oficijnyj Visnyk Ukrainy. 2005, №51.

22 Zakon Ukrainy "Pro osnovy nacionalnoi bezpeky Ukrainy”. Oficijnyj Visnyk Ukrainy. 2003, № 29.

23 Koncepcija vdoskonalennja derzhavnogo reguljuvannja pryrodnyh monopolij, shvalena Ukazom Prezydenta Ukrainy №921/2007 vid 27.09.2007. Oficijnyj Visnyk Ukrainy. 2007, №74. 
It was stipulated that commissions should be collegial organs and should consist of 5-9 members, including the head of the commission. Members of the commission should be appointed on an equal basis by the President of Ukraine and Verkhovna Rada of Ukraine at the request of the President of Ukraine. The head and the members of the commission should be relieved from office in accordance with the procedure mentioned above. Pursuant to the Concept, it is important to guarantee the independence of the members of the commissions from any political influence, as well as from any influence from the regulated market. Therefore, the selection of the members of the commissions shall be conducted on the basis of professional characteristics (the prospective candidate shall have higher field-oriented, economic or legal education), provided that the prospective candidate has work experience in the relevant sphere (managerial work experience on top positions in the relevant spheres not less than three years during the past ten years). The members of the commissions should be appointed on the basis of public procedure for the legal term of 5-7 years. According to the Concept, the commissions must carry out its tasks in a transparent manner. Transparency shall be encouraged by means of collegial decision making. Moreover, strict regulation of commission activity, obligatory annual report of a commission, guaranteed public access to tariff settlement and promulgation procedure shall be stipulated. The commission shall have the necessary financial resources. Special provisions of the Concept shall be devoted to the issues of cooperation of the commissions with other state bodies. It was planned that the commissions should provide the Verkhovna Rada of Ukraine and the President of Ukraine with annual reports on their activity. The Cabinet of Ministers of Ukraine communicates with the commissions regarding the development of state policy in the relevant spheres of natural monopolies and adjacent markets and approves the license payments at the requests of the commissions. The Antimonopoly Committee of Ukraine communicates with the commissions on anti-trust issues.

Therefore, it can be concluded that the Concept of Enhancement of Natural Monopolies State Regulation was a very progressive document in consideration of the EU requirements to the legal status of energy regulatory authorities, mentioned in Part 1 of this article, primarily, regarding the establishment of the energy regulator, appointment of its members and cooperation with other state bodies.

It should be mentioned that the idea to separate the energy regulator from the system of state executive bodies in order to encourage its independence was popular among the specialists from the period of its establishment, e.g., pursuant to Article 1 of the Draft Law "On National Energy Regulatory Commission" (which was registered in the Verkhovna Rada of Ukraine on 18 January, 2008; register №1372), a regulator was defined as a regulatory authority that works on the basis of collegial principle ${ }^{24}$. However, this Draft Law was excluded from consideration on 23 December, 2010.

24 Proekt Zakonu Ukrainy "Pro Nacionalnu komisiju reguljuvannja energetyky Ukrainy” №1372 vid 18.01.2008. [interactive]. [accessed 2013-08-14]. <http://w1.c1.rada.gov.ua/pls/zweb2/webproc4_ 1 ?pf3511=31396> . 


\subsection{National Communal Services Regulatory Commission}

As mentioned before, the sphere of district heating supply was defined as a sphere of natural monopolies pursuant to Article 5 of the Law of Ukraine "On Natural Monopolies". Heat generation (except the use of heat only for internal production needs) in volumes exceed the level stipulated by rules and conditions of conduct of entrepreneurial activity in heat generation (license conditions) was referred to adjacent markets in accordance with Article 6 of this Law.

The Concept of Enhancement of Natural Monopolies State Regulation stressed the necessity to establish the commissions in all spheres of natural monopolies in accordance with the Law of Ukraine "On Natural Monopolies", inter alia, in the sphere of communal services (district heating, water supply and sanitation). It should be mentioned that at the moment of approval of this Concept, the state regulation of the activity of the subjects of natural monopolies in the sphere of district heating, water supply and sanitation was conducted by the Ministry of Housing and Communal Economy of Ukraine, the Council of Ministers of the Autonomous Republic of Crimea, local state administrations and executive bodies of local self-government bodies.

The necessity to establish a special regulatory authority in the sphere of communal services was stressed in the Concept of Pricing in the Sphere of Housing and Communal Services approved by Presidential Decree №1324/2007 of 28 December 200725. However, the organizational legal form of such regulator was not strictly stipulated by this document. According to one provision of the Concept, the state regulation in the sphere of housing and communal services shall be conducted by the Cabinet of Ministers of Ukraine, the state regulatory body in the sphere of communal services, other state executive bodies, as well as by the local self-government bodies. Based on this provision, it could be concluded that the state regulatory authority was considered as an executive state body. However, according to another provision of the Concept, during the transition period (until the establishment of state regulatory bodies in concrete spheres) the functions of the state regulation shall be conducted by the state government bodies in relevant spheres and local self-government bodies that settle prices/tariffs for district cold and hot water supply and sanitation, as well as district heating supply. Therefore, it can be concluded that the Concept also supports the approach of the separation of regulatory functions in the sphere of communal services from governmental functions and the establishment of the special regulatory authority.

In furtherance of the proposal of the establishment of the national regulator in the sphere of communal services, the Concept of the Development of the System of State Regulation of the Activity of the Subjects of Natural monopolies was approved by Order of the Cabinet of Ministers of Ukraine №932-p of 09 July $2008^{26}$. According to this act,

25 Koncepcija cinoutvorennja u sferi komunalnyh poslug, shvalena Ukazom Prezydenta Ukrainy №1324 /2007 vid 28.12.2007. Oficijnyj Visnyk Ukrainy. 2008, №1.

26 Koncepcija rozvytku systemy derzhavnogo reguljuvannja dijalnosti subjektiv pryrodnyh monopolij na rynku komunalnyh poslug, shvalena Rozporjadzhennjam Kabinetu Ministriv Ukrainy №932-r vid 09.07.2008. Oficijnyj Visnyk Ukrainy. 2008, №51. 
the establishment of the conceptual framework of the operation of the state regulation system and adequate conditions for the communal services market development, distinction of functions of government and regulation, the definition of the authority responsible for the state regulation of the subjects of natural monopolies and frames of its responsibility are the main tasks of the reforms of the system of the state regulation of the subjects of natural monopolies. Pursuant to this Concept, the reforms of the system of the state regulation of the natural monopolies in the sphere of communal services shall be conducted in two stages. During the first stage, the regulatory duties shall be imposed on the special department of the Ministry of Housing and Communal Economy of Ukraine, whereas during the second stage, the regulatory authority with a network of territorial representative offices shall be established. Special attention is paid to the issue of encouragement of independence of the regulator in the sphere of communal services. Thus, the norms regarding the legal status of the regulatory authority, the establishment procedure, the list of regulatory functions, the regulatory decision-making procedure, the liability of the regulatory authority shall be the framework for independent regulatory decision-making. Therefore, the organizational legal form of the regulatory authority in the sphere of communal services is not defined by the Concept. However, considering the provisions regarding the necessity of the encouragement of the independent regulatory decision-making, it can be concluded that, according to the Concept, the regulatory authority in the sphere of communal services shall have a special legal status, different from the legal status of the state executive body.

The idea of the establishment of the independent regulator in the sphere of communal services was externalized in 2010, when the Draft Law "On National Communal Services Market Regulatory Commission" was registered in the Verkhovna Rada of Ukraine. This Law was approved by the Parliament of Ukraine on 9 July, 2010 (register №2479-VI) and entered into force on 22 July, 2010 (the current title of this Law is the Law of Ukraine "On State Regulation in the Sphere of Communal Services") ${ }^{27}$. The Law stipulated the establishment of an independent regulatory authority in the sphere of heating, district water supply and sanitation. It should be mentioned that during the transition period the regulatory duties in the sphere of communal services were imposed on the National Electricity Regulatory Commission (not on the special department of the Ministry of Housing and Communal Economy of Ukraine, as it was stipulated in the Concept of the Development of the System of State Regulation of the Activity of the Subjects of Natural Monopolies).

As to the organizational legal form of the National Communal Services Market Regulatory Commission, the Law mentioned above defined the Commission as a state collegial body of executive power. However, such type of state bodies was not defined by the Constitution of Ukraine. It can be assumed that the legislator stressed the peculiarities of the legal status of the regulator by such definition of its organizational legal form. Considering the further legislative initiatives, it can be concluded that this provision was one of the first attempts to separate the regulators of natural monopolies from the system of state executive bodies.

27 Zakon Ukrainy "Pro Nacionalnu komisiju reguljuvannja rynku komunalnyh poslug Ukrainy". Oficijnyj Visnyk Ukrainy. 2010, №55. 


\section{Legal Status of National Regulatory Authorities in the Energy Sector of Ukraine in the Conditions of the Current Administrative Reform}

Presidential Decree "On Optimization of the System of Central State Executive Bodies” №1085/2010 of 09 December 2010 is considered as one of the main important current stages of the administrative reform in the Ukraine. The new scheme of central state executive bodies is approved by this legal act. However, according to this Presidential Decree, the national natural monopolies regulatory commissions are not among the central state executive bodies. This position was supported later by the Parliament of Ukraine in the Law of Ukraine "On Central State Executive Bodies" №3166-VI of 17 March 2011. This Law also does not include the national natural monopolies regulatory commissions in the group of central state executive bodies.

It shall be stressed that the Presidential Decree was not a first official step on the way to the special status of the natural monopolies regulators. A few months before its approval and a few months after the approval of the Law of Ukraine "On National Communal Services Market Regulatory Commission", on 7 October, 2010 the Law of Ukraine "On Changes to Some Legal Acts of Ukraine in order to Bring it in Line with the Constitution of Ukraine" №2592-VI was approved ${ }^{28}$. As defined in the title of this Law, its main aim was to bring some laws in line with the Constitution of Ukraine (considering the termination of the constitutional reform of 2004 by Decision of the Constitutional Court of Ukraine №20-рп/2010 of 30 September $2010^{29}$ ). However, the provisions stipulated in this Law referred not only to the constitutional changes mentioned above, e.g., the status of the national natural monopolies regulatory commissions was changed by this Law. In accordance with Article 11 of the Law of Ukraine "On Natural Monopolies” (in wording of Law of Ukraine №2592-VI), the commissions are defined as state collegial bodies (not central state executive bodies).

The approval of the Law of Ukraine "On Changes to Some Legal Acts of Ukraine Regarding National Commissions that Conduct State Regulation of Natural Monopolies, in the Sphere of Communication and Informatization, Bond and Financial Markets" №3610-VI of 07 July $2011^{30}$ was the next step on the way of the separation of the national natural monopolies regulatory commissions from the system of state executive bodies. According to this Law, the legal status of all commissions that conduct state

28 Zakon Ukrainy "Pro vnesennja zmin do dejakyh zakonodavchyh aktiv Ukrainy shhodo pryvedennja ih u vidpovidnist iz Konstytucijeju Ukrainy”. Oficijnyj Visnyk Ukrainy. 2010, №79.

29 Rishennja Konstytucijnogo Sudu Ukrainy u spravi za konstytucijnym podannjam 252 narodnyh deputativ Ukrainy shhodo vidpovidnosti Konstytucii Ukrainy (konstytucijnosti) Zakonu Ukrainy "Pro vnesennja zmin do Konstytucii Ukrainy” vid 8 grudnja 2004 roku №2222-IV (sprava pro doderzhannja procedury vnesennja zmin do Konstytucii Ukrainy) №20-rp/2010 vid 30.09.2010. Oficijnyj Visnyk Ukrainy. 2010, №72/1.”

30 Zakon Ukrainy "Pro vnesennja zmin do dejakyh zakonodavchyh aktiv Ukrainy shhodo nacionaлnyh komisij, shho zdijsnjujut derzhavne reguljuvannja pryrodnyh monopolij, u sferi zvjazku ta informatyzacii, rynkiv cinnyh paperiv i finansovyh rynkiv” №3610-VI vid 07.07.2011. Golos Ukrainy. 2011, №145. 
regulation in the sphere of natural monopolies, as well as in the sphere of bond and financial markets, was unified.

According to Article 11 of the Law of Ukraine "On Natural Monopolies", national natural monopolies regulatory commissions are state collegial bodies established and liquidated by the President of Ukraine. Commissions are responsible to the President of Ukraine and accountable to the Verkhovna Rada of Ukraine.

Commissions conduct its activity on the basis of the regulations approved by the President of Ukraine. At the present moment, the National Energy Regulatory Commission conducts its activity on the basis of the Regulation approved by Presidential Decree №1059/2011 of 23 November $2011^{31}$, whereas the National Communal Services Regulatory Commission - on the basis of the Regulation approved by Presidential Decree №1073/2011 of 23 November .2011 ${ }^{32}$. As a collegial body, the commission consists of the head and six members of the commission, which are appointed and dismissed by the President of Ukraine by means of the approval of the relevant Decree. The head and the members of the commission are appointed for six years. One person can be the head and/ or a member of the commission for no longer than two terms in succession.

However, the process of the transformation of the legal status of national natural monopolies regulatory commissions has not finished yet. The Constitution of Ukraine does not define such type of state bodies as a state collegial body or a national natural monopoly regulatory commission. The Constitution of Ukraine includes a capable list of the responsibilities of the President of Ukraine. As to the responsibilities of establishment of state bodies, the President of Ukraine establishes, reorganizes and liquidates the ministries and other central state executive bodies and courts at the request of the Prime Minister of Ukraine, pursuant to Article 106 of the Constitution of Ukraine. However, there are no responsibilities on establishment of state collegial bodies or national natural monopolies regulatory commissions, as well as responsibilities regarding the appointment and dismissal of its management and members and approval of the regulations on such bodies. Therefore, the responsibilities of the President of Ukraine regarding the national regulatory authorities are stipulated by the laws of Ukraine, not by the Constitution of Ukraine. However, there is a legal position of the Constitutional Court of Ukraine, regarding the responsibilities of the President of Ukraine, which are defined by the Constitution of Ukraine and provided in several decisions. In particular, according to Decision of the Constitutional Court of Ukraine №7-pп/2003 of 10 April $2003^{33}$, the responsibilities of the President of Ukraine are capably defined by the Constitution of Ukraine, therefore, it is impossible to approve the laws to stipulate his

31 Ukaz Prezydenta Ukrainy "Pro Nacional'nu komisiju, shho zdijsnjuje derzhavne reguljuvannja u sferi energetyky”. Oficijnyj Visnyk Ukrainy. 2011, №94.

32 Ibid.

33 Rishennja Konstytucijnogo Sudu Ukrainy №7-rp/2003 vid 10.04.2003 u spravi za konstytucijnym podannjam Prezydenta Ukrainy pro oficijne tlumachennja polozhen chastyn rugoi, tretoi statti 17 , chastyny drugoi statti 27 Zakonu Ukrainy "Pro status narodnogo deputata Ukrainy" (sprava pro garantii dijalnosti narodnogo deputata Ukrainy). Oficijnyj Visnyk Ukrainy. 2003, №17. 
other responsibilities (rights and obligations). Pursuant to Decision of the Constitutional Court of Ukraine №14-pп/2008 of 08 July $2008^{34}$, the President of Ukraine can conduct normative legal regulations of the activity of bodies that he can establish and govern in accordance with his constitutional responsibilities.

\section{Conclusions}

Considering the facts mentioned above, it can be concluded that the Ukraine decided to establish a separate group of independent state bodies that are not included in the system of state executive bodies. The regulatory authorities in the energy sector - the National Energy Regulatory Commission and the National Communal Services Regulatory Commission - are part of this group. As to the energy regulator, such changes in general are in line with the main requirements of the EU legislation, primarily with Directive 2009/72/EC of the European Parliament and the Council of 13 July 2009, concerning common rules for the internal market in electricity and repealing Directive 2003/54/EC and Directive 2009/73/EC of the European Parliament and the Council of 13 July 2009, concerning common rules for the internal market in natural gas and repealing Directive 2003/55/EC. However, it is necessary to include special provisions in the Constitution of Ukraine, regarding the state collegial bodies/national regulatory commissions, in particular, concerning the organizational legal form and the establishment procedure of such bodies, the appointment and dismissal procedure for their members and the peculiarities of the relations of these bodies with the President of Ukraine, the Parliament of Ukraine and the Government of Ukraine.

\section{References}

Commission Staff Working Paper. Interpretative Note on Directive 2009/72/EC Concerning Common Rules for the Internal Market in Electricity and Directive 2009/73/ EC Concerning Common Rules for the Internal Market in Natural Gas. Brussels, 22 January, 2010 [interactive]. [accessed on 14-08-2013]. <http://ec.europa.eu/energy/ gas_electricity/interpretative_notes/doc/ implementation_notes/2010_01_21_the regulatory_authorities.pdf $>$.

Decision of the Ministerial Council of the Energy Community D/2011/02/MC-EnC: Decision of the implementation of Directive 2009/72/EC, Directive 2009/73/EC, Regulation (EC) №714/2009 and Regulation (EC) №715/2009 and amending Articles 11 and 59 of the Energy Community Treaty.

34 Rishennja Konstytucijnogo Sudu Ukrainy №14-rp/2008 vid 08.07.2008 u spravi za konstytucijnym podannjam 60 narodnyh deputativ Ukrainy shhodo vidpovidnosti Konstytucii Ukrainy (konstytucijnosti) polozhen abzaciv pershogo, drugogo chastyny pershoi, chastyny drugoi statti 11 Zakonu Ukrainy "Pro pryrodni monopolii'” (sprava pro nacionalni komisii reguljuvannja pryrodnyh monopolij). Oficijnyj Visnyk Ukrainy. - 2008, №2. 
[interactive]. [accessed on 14-08-2013]. $<$ http://www.energy-community.org/pls/ portal/docs/1146182.PDF>.

Directive 2009/72/EC of the European Parliament and the Council of 13 July 2009 concerning common rules for the internal market in electricity and repealing Directive 2003/54/EC [2009] OJ, L211/55.

Directive 2009/73/EC of the European Parliament and the Council of 13 July 2009 concerning common rules for the internal market in natural gas and repealing Directive 2003/55/EC [2009] OJ, L211/94.

Gilardi, F. Explaining Delegation to Independent Regulatory Agencies: The Role of Political Uncertainty. [interactive]. [accessed on 1408-2013]. <http://onlinelibrary.wiley.com/ doi/10.1002/j.1662-6370.2002.tb00336.x/ pdf $>$.

Hanretty, C. and Koop, C. De Jure and de Facto Independence of Regulatory Agencies. March, 2010 [interactive]. [accessed on 14-08-2013]. <http://chrishanretty.co.uk/ blog/wp-content/uploads/2010/03/hanretty_ koop_psa2010.pdf $>$.

Larsen, A.; Pedersen, L.H.; Sorensen, E.M.; Olsen, O.J. Independent Regulatory Authorities in Europe. [interactive]. [accessed on 14-08-2013]. <http://sessa. eu.com/documents/wp/D73.1-Larsen.pdf $>$.

Vasconcelos, J. Energy Regulation in Europe: Regulatory Policies and Politics of Regulation. European Review of Energy Markets. 2009, (3, 3) [interactive]. [accessed on 14-08-2013]. <http://www-55.mech. kuleuven.be/european-review-of-energymarket/EREM_9-_Comment_Jorge_ Vasconcelos.pdf $>$.

Vashhenko, Ju. Problemy pravovogo statusu Nacionalnoi komisii reguljuvannja rynku komunalnyh poslug Ukrainy. Visnyk Kyivskogo nacionalnogo universytetu imeni Tarasa Shevchenka: jurydychni nauky. 2010, 85: 22-26.

Vashhenko, Ju. Nacionalni komisii reguljuvannja pryrodnyh monopolij v systemi organiv derzhavnoi vlady v Ukraini Pivdenno- ukrainskyj pravnychyj chasopys, 2012, №3 S.137-139.

Zakon Ukrainy "Pro vnesennja zmin do dejakyh zakonodavchyh aktiv Ukrainy shhodo nacionalnyh komisij, shho zdijsnjujut derzhavne reguljuvannja pryrodnyh monopolij, $\mathrm{u}$ sferi zvjazku ta informatyzacii, rynkiv cinnyh paperiv i finansovyh rynkiv". Golos Ukrainy, 2011, №145.

Zakon Ukrainy "Pro vnesennja zmin do dejakyh zakonodavchyh aktiv Ukrainy shhodo pryvedennja ih u vidpovidnist iz Konstytucijeju Ukrainy”. Oficijnyj Visnyk Ukrainy. 2010, №79.

Zakon Ukrainy "Pro elektroenergetyku”. Oficijnyj Visnyk Ukrainy. 1997, №46.

Zakon Ukrainy "Pro Nacionalnu komisiju reguljuvannja rynku komunalnyh poslug Ukrainy”. Oficijnyj Visnyk Ukrainy. 2010, №55.

Zakon Ukrainy "Pro osnovy nacionalnoi bezpeky Ukrainy". Oficijnyj Visnyk Ukrainy. 2003, №29.

Zakon Ukrainy "Pro pryrodni monopolii"”. Vidomosti Verhovnoi Rady Ukrainy. 2000, №30.

Zakon Ukrainy "Pro ratyfikaciju Protokolu pro pryjednannja Ukrainy do Dogovoru pro zasnuvannja Energetychnogo Spivtovarystva”. Oficijnyj Visnyk Ukrainy. 2011, №1.

Zakon Ukrainy "Pro centralni organy vykonavchoi vlady”. Golos Ukrainy, 2011, №65.

Koncepcija vdoskonalennja derzhavnogo reguljuvannja pryrodnyh monopolij, shvalena Ukazom Prezydenta Ukrainy №921/2007 vid 27.09.2007. Oficijnyj Visnyk Ukrainy. 2007, №74.

Koncepcija rozvytku systemy derzhavnogo reguljuvannja dijalnosti subjektiv pryrodnyh monopolij na rynku komunalnyh poslug, shvalena Rozporjadzhennjam Kabinetu Ministriv Ukrainy №932-r vid 09.07.2008. Oficijnyj Visnyk Ukrainy. 2008, №51.

Koncepcija cinoutvorennja u sferi komunalnyh poslug, shvalena Ukazom Prezydenta Ukraiy 
№1324/2007 vid 28.12.2007. Oficijnyj Visnyk Ukrainy. 2008, №1.

Melnyk, R.; Petrov, Je. Fantom u systemi organiv derzhavnoi vlady abo do pytannja pro pravovyj status nacionalnyh komisij reguljuvannja pryrodnyh monopolij. Visnyk Zaporizkogo nacionalnogo universytetu. 2012, 1(1): 214-219.

ProektZakonuUkrainy "Pro Nacionalnukomisiju reguljuvannja energetyky Ukrainy” №1372 vid 18.01.2008. [interactive]. [accessed 201308-14]. <http://w1.c1.rada.gov.ua/pls/zweb2/ webproc4_1?pf3511=31396>.

Rishennja Konstytucijnogo Sudu Ukrainy №7-rp/2003 vid 10.04.2003 u spravi za konstytucijnym podannjam Prezydenta Ukrainy pro oficijne tlumachennja polozhen chastyn drugoi, tretoi statti 17 , chastyny drugoi statti 27 Zakonu Ukrainy "Pro status narodnogo deputata Ukrainy" (sprava pro garantii dijalnosti narodnogo deputata Ukrainy). Oficijnyj Visnyk Ukrainy. 2003, №17.

Rishennja Konstytucijnogo Sudu Ukrainy №14-rp/2008 vid 08.07.2008 u spravi za konstytucijnym podannjam 60 narodnyh deputativ Ukrainy shhodo vidpovidnosti Konstytucii Ukrainy (konstytucijnosti) polozhen abzaciv pershogo, drugogo chastyny pershoi, chastyny drugoi statti 11 Zakonu Ukrainy "Pro pryrodni monopolii"” (sprava pro nacionalni komisii reguljuvannja pryrodnyh monopolij). Oficijnyj Visnyk Ukrainy. - 2008, №2.

Rishennja Konstytucijnogo Sudu Ukrainy u spravi za konstytucijnym podannjam 252 narodnyh deputativ Ukrainy shhodo vidpovidnosti Konstytucii Ukrainy (konstytucijnosti) Zakonu Ukrainy "Pro vnesennja zmin do Konstytucii Ukrainy" vid 8 grudnja 2004 roku №2222-IV (sprava pro doderzhannja procedury vnesennja zmin do Konstytucii Ukrainy) №20-rp/2010 vid 30.09.2010. Oficijnyj Visnyk Ukrainy. 2010, №72/1.Ukaz Prezydenta Ukrainy “Pro zahody shhodo zabezpechennja dijalnosti Nacionalnoi komisii z pytan reguljuvannja elektroenergetyky Ukrainy". Urjadovyj kurjer. 1995, №43-44.

Ukaz Prezydenta Ukrainy "Pro zminy u strukturi centralnyh organiv vykonavchoi vlady". Oficijnyj Visnyk Ukrainy. 1999, №50.

Ukaz Prezydenta Ukrainy "Pro Nacionalnu komisiju z pytan reguljuvannja elektroenergetyky". 1994. [interactive]. [accessed 2013-08-14]. <http://zakon4.rada.gov.ua/ laws/show/738/94>.

Ukaz Prezydenta Ukrainy "Pro Nacionalnu komisiju, shho zdijsnjuje derzhavne reguljuvannja u sferi komunalnyh poslug". Oficijnyj Visnyk Ukrainy. 2011, №94.

Ukaz Prezydenta Ukrainy "Pro Nacionalnu komisiju, shho zdijsnjuje derzhavne reguljuvannja u sferi energetyky". Oficijnyj Visnyk Ukrainy. 2011, №94.

Ukaz Prezydenta Ukrainy "Pytannja Nacionalnoi komisii reguljuvannja elektroenergetyky Ukrainy”. Oficijnyj Visnyk Ukrainy. 2000, №11.

Ukaz Prezydenta Ukrainy "Pytannja Nacionalnoi komisii reguljuvannja elektroenergetyky Ukrainy". Oficijnyj Visnyk Ukrainy. 1998, №16.

Ukaz Prezydenta Ukrainy №1784/2005 vid 19.12.2005 "Pro vnesennja zmin do Shemy organizacii ta vzajemodii centralnyh organiv vykonavchoi vlady". Oficijnyj Visnyk Ukrainy. 2005, №51.

Ukaz Prezydenta Ukrainy "Pro optymizaciju centralnyh organiv vykonavchoi vlady". Urjadovyj kurjer, 2010, №234. 


\title{
UKRAINOS NACIONALINĖS REGULIAVIMO INSTITUCIJOS ENERGETIKOS SEKTORIUJE: TEISINIO STATUSO PROBLEMOS EUROPOS INTEGRACIJOS IR ADMINISTRAVIMO REFORMOS KONTEKSTE
}

\author{
Yuliya Vashchenko \\ Kijevo nacionalinis Taraso Ševčenkos universitetas, Ukraina
}

Santrauka. Šiuo metu Ukrainoje vyksta administracinè reforma, todèl mokslininkai, o bütent administracinès teisés specialistai, privalo teikti efektyvius pasiülymus dèl uždaviniu, susijusiu su viešuju instituciju sistemos optimizavimu, sprendimo. Apskritai reguliavimo instituciju teisinio statuso, tarp ju ir energetikos reguliavimo instituciju teisinio statuso (Nacionaline energetikos reguliavimo komisija ir Nacionaline komunaliniu paslaugu rinkos reguliavimo komisija) klausimai yra vieni iš svarbiausių uždaviniu. Prieš kuri laika tokiu instituciju tipas bei vieta Ukrainos viešojo administravimo instituciju sistemoje buvo griežtai nustatyti Ukrainos istatymų leidejo. Šie dariniai buvo vykdomosios valdžios institucijų dalis ir turëjo centriniu vykdomosios valdžios instituciju statusa. Tačiau dèl vykdomosios valdžios instituciju sistemos reformos pastaruoju metu ivyko svarbūs pasikeitimai. Šios reformos prasidejo nuo Prezidento dekreto „Dél vykdomosios valdžios instituciju sistemos optimizavimo“, priimto 2010 m. gruodžio 9 d., véliau, t. y. 2011 m. kovo 17 d., buvo priimtas Ukrainos istatymas Dél centriniu valstybiniu vykdomosios valdžios instituciju, taip pat $2011 \mathrm{~m}$. liepos 7 d. buvo priimtas Ukrainos ìstatymas Dèl tam tikru Ukrainos teisés aktu, susijusiu su nacionalinemis komisijomis, atliekančiomis natüraliu monopoliju valstybini reguliavima telekomunikaciju, informatizacijos, obligaciju ir finansu srityje, pakeitimo. Nacionalines komisijos buvo atskirtos nuo vykdomosios valdžios instituciju sistemos, suteikiant joms valstybiniu kolegialiu instituciju statusą. Pagal naujaji teisini reguliavima šios institucijos yra steigiamos Ukrainos Prezidento, jos yra atsakingos Ukrainos Prezidentui bei atskaitingos Ukrainos istatymu leidžiamajai valdžiai - Verkhovna Rada. Tokie pakeitimai yra susije su ES teises reikalavimais, keliamais nacionaliniu energetikos reguliavimo instituciju nepriklausomumui, bütent Europos Parlamento ir Tarybos 2009 m. liepos 13 d. direktyva 2009/72/EB del elektros energijos vidaus rinkos bendruju taisykliu, panaikinanti Direktyva 2003/54/ EB, bei Europos Parlamento ir Tarybos $2009 \mathrm{~m}$. liepos 13 d. direktyva 2009/73/EB del gamtiniu duju vidaus rinkos bendruju taisykliu, panaikinanti Direktyva 2003/55/EB. Tačiau, atsižvelgiant i Ukrainos Konstitucijos nuostatas, valstybiniu kolegialiu instituciju, tarp ju ir energetikos reguliuotoju, teisinis statusas iki šiolei nèra aiškus. Ukrainos Konstitucija neapibrezžia tokiu dariniu kolegialiomis institucijomis. Atsižvelgdama i ES reikalavimus bei Ukrainos patirti, sio straipsnio autore remia specialaus teisinio statuso (kolegialiu instituciju) suteikima energetikos reguliuotojams, tačiau rekomenduoja šiuos klausimus atspindèti Ukrainos Konstitucijoje.

Reikšminiai žodžiai: energetikos reguliavimas, energetikos reguliuotojas, energetikos politika, nacionalines reguliavimo institucijos, administravimo reforma. 
Yuliya Vashchenko, Kijevo nacionalinio Taraso Ševčenkos universiteto Teisès fakulteto Administracinès teisès katedros docentè. Mokslinių tyrimų kryptys: administracinè teisè, energetikos teisè, finansų teisè, žmogaus teisès.

Yuliya Vashchenko, Taras Shevchenko National University of Kyiv, Faculty of Law, Department of Administrative Law, Associate Professor. Research interests: administrative law, energy law, financial law, human rights law. 